\title{
HUBUNGAN ANTARA FAKTOR IBU DENGAN STATUS GIZI BALITA DI PUSKESMAS HINAI KIRI KECAMATAN SECANGGANG KABUPATEN LANGKAT TAHUN 2020
}

\section{Correlation Between Mother Factor And Nutrition Status Of Toddlers In Hinai Kiri Public Health Center (Puskesmas Hinai Kiri) Secanggang Langkat District 2020}

\author{
Arnof Yerni $^{1}$, Setia Sihombing ${ }^{2}$ \\ 1. STIKES Putra Abadi Langkat Stabat
}

\section{Riwayat artikel}

Diajukan: September 2020

Diterima: Maret 2021.

\section{PenulisKorespondensi: \\ - Arnof Yerni \\ - STIKES Putra Abadi \\ Langkat Stabat \\ - arnofy@yahoo.com}

\section{Kata Kunci: \\ Gizi Balita}

\begin{abstract}
Abstrak
Balita merupakan kelompok umur yang paling rawan menderita akibat kekurangan gizi dan termasuk kelompok rawan gizi .Penelitian ini menggunakan pendekatan asosiatif kolerasi dengan jenis penelitian survei yang menyoroti hubungan antara variabel penelitian dan menguji hipotesis yang telah dirumuskan. Populasi pada penelitian ini seluruh ibu yang mempunyai anak balita yang berobat jalan pada poli Puskesmas Hinai Kiri Kecamatan Secanggang Kabupaten Langkat Sebanyak 54 orang dan teknik pengambilan sampel adalah accidental sampling

Hasil analisis univariat diketahui pengetahuan tinggi sebanyak 33 orang $(61,1 \%)$,umur paling banyak tua sebanyak 29 orang $(53,7 \%)$ dan pendidikan tinggi sebanyak 33 orang $(61,1 \%)$ dan ibu yang tidak bekerja sebanyak 32 orang $(59,3 \%)$ serta jumlah anak paling banyak tinggi sebanyak 28 orang $(51,9)$ dan penghasilan keluarga rendah sebanyak 28 orang $(51,9 \%)$ dan status Gizi balita paling banyak baik sebanyak baik 38 orang $(70,4 \%)$.

Sedangkan analisis bivariat menggunakan uji chi square (CI 95\% dan $\alpha=0,05$ ) didapatkan hubungam pengetahuan dengan status gizi balita $(p-$ value $=0,009)$ dan hubungan umur dengan status gizi balita ( $\mathrm{p}$-value $=0.039$ ) hubungan pendidikan dan status gizi baita ( $\mathrm{p}$-value $=0,003$ ) dan hubungan pekerjaan dengan Status gizi balita ( $\mathrm{p}$ value $=0,045)$ dan hubungan pengehasilan dengan status gizi balita $(\mathrm{P}-$ Value $=0,002)$ dan hubungan jumlah anak dengan status gizi balita $(\mathrm{P}-$ Value $=0,003)$.
\end{abstract}

\section{Abstract}

Toddlers is the age group that is most vulnerable to nutritional deficiencies and is considered a nutritional vulnerable group. This research was done using a correlative association approach, beinga survey research concerning the correlation between research variables and confirming the proposed hypothesis. The population of this research was all outpatient mothers with toddlersin the polyclinic of Puskesmas Hinai Kiri (Hinai Kiri Public Health Center) Kecamatan Secanggang Kabupaten Langkat numbering 54 people, with accidental sampling technique.

From the univariate analysis result was found that 33 mothers $(61,1 \%)$ have high knowledge,29 mothers $(53,7 \%)$ were from the old age group, 33 mothers have high education $(61,1 \%)$ and 32 mothers $(59,3 \%)$ being unemployed with 28 mothers $(51,9 \%)$ have high number of children, 28 mothers $(51,9 \%)$ from a low family income group, and 38 mothers $(70,4 \%)$ have good toddler nutrition status.

From the bivariate analysis result using chi squaretest (CI 95\% and $\alpha=0,05$ ) was found that the correlation between knowledge and toddler nutrition statsus is ( $\mathrm{p}$ - value = $0,009)$, the correlation between age and toddler nutrition status is ( $\mathrm{p}$-value $=0.039$ ), the correlation between education and toddler nutrition status is ( $\mathrm{p}$-value $=0,003$ ), the correlation between occupation and toddler nutrition status is ( $p$-value $=0,045)$, the correlation between income and toddler nutrition status is ( $\mathrm{P}-$ Value $=0,002)$, and the correlation between number of childern and toddler nutrition status is $(\mathrm{P}-\mathrm{Value}=0,003)$. 


\section{Pendahuluan}

Angka kematian ibu berguna untuk menggambarkan tingkat kesadaran perilaku hidup sehat, status gizi, dan kesehatan ibu, sedangkan angka kematian bayi berhubungan dengan pendapatan keluarga, pendidikan ibu dan status gizi keluarga.Angka ini juga merupakan indikator terbaik untuk menilai pembangunan sosial ekonomi masyarakat secara menyeluruh. Angka kematian balita (AKABA) juga dapat menggambarkan faktor-faktor lingkungan yang berpengaruh terhadap kesehatan balita seperti gizi balita (Profil Kesehatan, 2017).

Penyebab utama kematian Ibu di Indonesia adalah perdarahan 30-35\%, toksiemia gravidarum (15-17\%), infeksi (2025,8\%)(Depkes, 2016). Sedangkan menurut Manuaba (2015) penyebab utama dari kematian bayi di Indonesia adalah asfiksia neonatorum (50-60\%), BBLR (25-30\%), infeksi (25-30\%).(Manuaba, 2015)

Anak balita merupakan kelompok yang mengalami pertumbuhan badan yang pesat sehingga memerlukan zat-zat gizi yang tinggi setiap $\mathrm{kg}$ berat badannnya.Balita ini juga merupakan kelompok umur yang paling rawan menderita akibat kekurangan gizi dan termasuk kelompok rawan gizi (Almatsier, 2013). Di Indonesia kelompok anak balita tertinggi pravalensinya untuk kekurangan gizi.Kelompok ini sulit dijangkau oleh berbagai upaya kegiatan perbaikan gizi dan kesehatan lainnya, karena tidak dapat datang sendiri ke tempat yang ditentukan tanpa diantar.

Masalah gizi dan kesehatan Indonesia dimasa yang akan datang semakin komplek, saling terkait, penangananyapun membutuhkan tenaga yang mempunyai kompetensi lebih tinggi. Kompetensi diperlukan untuk memenuhi tantangan masalah gizi dan kesehatan di masa 10-20 tahun mendatang.Peran lembaga pendidikan sangat diharapkan untuk memenuhi tenaga dengan kompetensi tinggi yang dapat memenuhi tuntutan zaman (Akdon, 2014).

Menurut Supariasa (2012 banyak faktor yang menjadi penyebab utama terjadinya kekurangan gizi pada anak balita antara lain adalah intake makanan yang kurang dalam kuantitas atau kualitasnya, lingkungan, pola asuh anak, jumlah tanggungan keluarga, faktor ibu, pola dan gaya hidup keluarga, sosial ekonomi dan budaya.Di antara penyebab tersebut yang paling besar pengaruhnya adalah faktor ibu karena pengasuhan dan pemenuhan gizi balita sangat tergantung pada ibu, sehingga pengaruh ibu sangat menetukan terjadinya masalah kesehatan yang berkaitan dengan status gizi balita.(Supariasa, 2012)

Berdasarkan pertimbangan dan hal-hal di atas peneliti merasa perlu mengadakan penelitian dengan topik "Hubungan antara faktor ibu dengan status gizi balita di Puskesmas Hinai Kiri kecamatan Secanggang kabupaten Langkat tahun 2020”.

\section{Metodologi}

Penelitian ini menggunakan metode cross sectional dengan pendekatan asosiatif korelasi dengan tujuan untuk mempelajari adanya hubungan antara variable independen dengan variable dependen. Penelitian ini dilakukan di Puskesmas Hinai Kiri Kecamatan Secanggang Kabupaten Langkat Propinsi sumatera Utara dengan sasaran ibu yang memiliki balita dengan pengambilan sampelnya secara Accidental Sampling sebanyak 54 orang.

\section{Hasil dan Pembahasan}

Tabel 1 Distribusi Frekuensi Pengetahauan responden di Pukesmas Hinai Kiri Kecamatan Secanggang Kabupaten Langkat tahun 2020.

\begin{tabular}{lll}
\hline Pengetahuan & Jumlah & $\mathbf{\%}$ \\
\hline Tinggi & 33 & 61,1 \\
Rendah & 21 & 38,9 \\
\hline Total & $\mathbf{5 4}$ & $\mathbf{1 0 0}$ \\
\hline
\end{tabular}

Dari tabel 1 menunjukkan mayoritas pengetahuan responden tinggi sebanyak 33 orang $(61,1 \%)$ dan pengetahuan rendah sebanyak 21 orang $(38,9 \%)$.

Tabel 2 Distribusi Frekuensi Umur Responden dii Puskesmas Hinai 
Kiri Kec. Secanggang Kab. Langkat Tahun 2020

\begin{tabular}{ccc}
\hline Agama & Jumlah & \% \\
\hline Muda & 25 & 46,3 \\
Tua & 29 & 53,7 \\
\hline Total & $\mathbf{5 4}$ & $\mathbf{1 0 0}$ \\
\hline \multicolumn{1}{c}{ Dari tabel } & 2 & menunjukkan \\
bahwa
\end{tabular}
mayoritas umur responden adalah muda sebanyak 29 orang $(53,7 \%)$ dan umur tua sebanyak 25 orang $(46,3 \%)$.

Tabel 3 Distribusi Frekuensi Pendidikan responden di Puskesmas Hinai Kiri Kec. Secanggang Kab.Langkat Tahun 2020

\begin{tabular}{lcc}
\hline $\begin{array}{l}\text { Pendidikan Orang } \\
\text { Tua }\end{array}$ & Jumlah & $\mathbf{\%}$ \\
\hline Tinggi & 33 & 61,1 \\
Rendah & 21 & 38,9 \\
\hline Total & $\mathbf{5 4}$ & $\mathbf{1 0 0}$ \\
\hline Dari tabel & 3 & menunjukkan \\
pendidikan responden yang didapatkan a \\
dalah tinggi sebanyak & 33 orang (61,1\%), \\
yang pendidikan rendah sebanyak 21 orang \\
$(38,9 \%)$.
\end{tabular}

Tabel 4 Distribusi Frekuensi Pekerjaan responden di Pukesmas Hinai Kiri Kec.Secanggang ,Kab. Langkat Tahun 2020

\begin{tabular}{lcc}
\hline $\begin{array}{l}\text { Pekerjaan Orang } \\
\text { Tua }\end{array}$ & Jumlah & \% \\
\hline Tidak Bekerja & 32 & 59,3 \\
Bekerja & 22 & 40,7 \\
\hline Total & $\mathbf{5 4}$ & $\mathbf{1 0 0}$ \\
\hline
\end{tabular}

Dari tabel 4 dapat dilihat mayoritas responden tidak bekerja sebanyak 32 orang $(59,3 \%)$ dan responden bekerja sebanyak 22 orang $(40,7 \%)$.

Tabel 5 Distribusi frekuensi Jumlah anak respondenDi Puskesmas Hinai Kiri Kec.Secanggang Kab. Langkat tahun 2020

\begin{tabular}{lcc}
\hline Jumlah anak & Jumlah & $\boldsymbol{\%}$ \\
\hline Rendah & 26 & 48,1 \\
Tinggi & 28 & 51,9 \\
\hline Total & $\mathbf{5 4}$ & $\mathbf{1 0 0}$ \\
\hline
\end{tabular}

Dari Tabel.5 menunjukkan jumlah anak responden mayoritas tinggi sebanyak 28 orang $(51,9 \%)$ dan rendah sebanyak 26 orang $(48,1 \%)$.

Tabel 6 Distribusi Frekuensi Penghasilan Responden di Puskesmas Selesai Kec.Selesai Kab.Langkat Tahun 2020

\begin{tabular}{|c|c|c|}
\hline $\begin{array}{l}\text { Penghasilan } \\
\text { keluarga }\end{array}$ & Jumlah & $\%$ \\
\hline Tinggi & 26 & 48,1 \\
\hline Rendah & 28 & 51,9 \\
\hline Total & 54 & 100 \\
\hline
\end{tabular}
penghasilan responden rendah sebanyak 28 orang $(51,9)$ dan penghasilan responden tinggi sebanyak 26 orang $(48,1 \%)$.

Tabel 7 Distribusi Frekuensi Status Gizi Balita di Puskesmas Hinai Kiri Kec.Secanggang Kab.Langkat Tahun 2020

\begin{tabular}{lcc}
\hline $\begin{array}{l}\text { Status Gizi } \\
\text { Balita }\end{array}$ & Jumlah & $\mathbf{\%}$ \\
\hline Baik & 38 & 70,4 \\
Buruk & 16 & 29,6 \\
\hline Total & $\mathbf{5 4}$ & $\mathbf{1 0 0}$ \\
\hline
\end{tabular}

Dari tabel 7 menunjukkan mayoritas status gizi balita baik sebanyak 38 orang $(70,4 \%)$ dan status gizi buruk sebanyak 16 orang $(29,6 \%)$.

\section{Analisis Bivariat}

Analisis bivariat bertujuan untuk mencari hubungan antara variabel, dalam hal ini adalah hubungan antara variabel bebas dengan variabel terikat yang telah dijelaskan di Bab III, seperti hubungan antara pengetahuan, Umur, Pendidikan Pekerjaan, Jumlah anak, Penghasilan keluarga dengan status gizi balita.

Tabel 8 Hubungan antara pengetahuan dengan status gizi balita di Puskesmas Hinai Kiri Kec.Secanggang Kab Langkat Tahun 2020 


\begin{tabular}{|c|c|c|c|c|c|c|c|c|}
\hline \multirow{3}{*}{$\begin{array}{l}\text { Pengeta } \\
\text { huan }\end{array}$} & \multicolumn{6}{|c|}{ Status Gizi Balita } & \multirow{3}{*}{$\begin{array}{l}\text { P- } \\
\text { Val } \\
\text { ue }\end{array}$} & \multirow{3}{*}{ OR } \\
\hline & \multicolumn{2}{|c|}{ Baik } & \multicolumn{2}{|c|}{ Kurang } & \multicolumn{2}{|c|}{ Total } & & \\
\hline & $\mathrm{N}$ & $\%$ & $\mathrm{~N}$ & $\%$ & $\mathrm{~N}$ & $\%$ & & \\
\hline Tinggi & 28 & 84,8 & 5 & 15,2 & 33 & 100 & 0,0 & 6.16 \\
\hline Kurang & 10 & 47,6 & 11 & 52,5 & 21 & 100 & 09 & 0 \\
\hline Total & 38 & 70,4 & 16 & 29,6 & 54 & 100 & & \\
\hline
\end{tabular}

ibu tinggi jumlah 33 orang (100\%) mayoritas pengetahuan tinggi status gizi baik sebanyak $28(84.8 \%)$ dan status gizi kurang sebanyak 5 orang $(15,2 \%)$. Dan Varaibel pengetahuan kurang sebanyak 21 orang $(100 \%)$ dimana status gizi baik sebanyak 10 orang $(47,6 \%)$ dan status gizi kurang sebanyak 11 orang $(52,5 \%)$.

Tabel 9 Hubungan Antara umur responden dengan status Gizi Balita di Puskesmas Hinai Kiri Kec Secanggang Kabupaten Langkat Tahun 2020.

\begin{tabular}{|c|c|c|c|c|c|c|c|c|}
\hline \multirow{3}{*}{$\begin{array}{l}\text { Umur } \\
\text { Ibu }\end{array}$} & \multicolumn{6}{|c|}{ Status Gizi Balita } & \multirow{3}{*}{$\begin{array}{l}\text { P- } \\
\text { Valu } \\
\mathrm{e}\end{array}$} & \multirow{3}{*}{ OR } \\
\hline & \multicolumn{2}{|c|}{ Baik } & \multicolumn{2}{|c|}{ Kurang } & \multicolumn{2}{|c|}{ Total } & & \\
\hline & $\mathrm{N}$ & $\%$ & $\mathrm{~N}$ & $\%$ & $\mathrm{~N}$ & $\%$ & & \\
\hline Muda & 22 & 88,0 & 3 & 12,0 & 25 & 100 & 0,03 & 3,92 \\
\hline Tua & 16 & 55,2 & 13 & 44,8 & 29 & 100 & 9 & 3 \\
\hline Total & 24 & $\mathbf{7 0 , 4}$ & 30 & 29,6 & 54 & 100 & & \\
\hline
\end{tabular}

Dari tabel tersebut Variabel umur ibu muda jumlah 25 orang (100\%) mayoritas umur ibu muda status gizi baik sebanyak $22(88,0 \%)$ dan status gizi kurang sebanyak 3 orang $(12,0 \%)$. Dan Varaibel umur tua banyak 29 orang(100\%) dimana status gizi baik sebanyak 16 orang $(55,2 \%)$ dan status gizi kurang sebanyak 13 orang (44,8\%). Dan Varaibel pendidkan rendah sebanyak 21 orang $(100 \%)$ dimana status gizi baik sebanyak 11 orang $(52,4 \%)$ dan status gizi kurang sebanyak 10 orang $(39,1 \%)$.

Tabel 10 Hubungan Antara pendidikan dengan Status Gizi Balita di Puskesmas Hinai Kiri Kecamatan Secanggang Kabupaten Langkat tahun 2020

\begin{tabular}{lllllllll}
\hline \multirow{2}{*}{$\begin{array}{l}\text { Pendidik } \\
\text { an }\end{array}$} & \multicolumn{9}{c}{ Status Gizi Balita } & P- & \\
\cline { 2 - 7 } & \multicolumn{2}{c}{ Baik } & \multicolumn{4}{c}{ Kurang } & \multicolumn{3}{c}{ Total } & OR \\
\cline { 2 - 7 } & $\mathrm{N}$ & $\%$ & $\mathrm{~N}$ & $\%$ & $\mathrm{~N}$ & $\%$ & ue & \\
\hline Tinggi & 27 & 81,8 & 6 & 18,2 & 33 & 100 & 0,0 & 6,6 \\
Rendah & 11 & 52,4 & 10 & 39,1 & 21 & 100 & 03 & 44 \\
\hline Total & $\mathbf{3 8}$ & $\mathbf{7 0 , 4}$ & $\mathbf{1 6}$ & $\mathbf{2 9 , 6}$ & $\mathbf{5 4}$ & $\mathbf{1 0 0}$ & & \\
\hline
\end{tabular}

Dari tabel tersebut Variabel pendidikan ibu tinggi jumlah 33 orang (100\%) mayoritas pendidikan tinggi status gizi baik sebanyak $27(81.8 \%)$ dan status gizi kurang sebanyak 6 orang $(18,2 \%)$. Dan Varaibel pendidkan rendah sebanyak 21 orang(100\%) dimana status gizi baik sebanyak 11 orang $(52,4 \%)$ dan status gizi kurang sebanyak 10 orang $(39,1 \%)$.

Tabel 11 Hubungan Antara Pekerjaan dengan Status Gizi Balita di Puskesmas Hinai Kiri Kecamtan Secanggang Kabupaten Langkat tahun 2020

\begin{tabular}{|c|c|c|c|c|c|c|c|c|}
\hline \multirow{3}{*}{ Pekerjaan } & \multicolumn{6}{|c|}{ Status Gizi Balita } & \multirow{3}{*}{$\begin{array}{l}\text { P- } \\
\text { Val } \\
\text { ue }\end{array}$} & \multirow{3}{*}{ OR } \\
\hline & \multicolumn{2}{|c|}{ Baik } & \multicolumn{2}{|c|}{ Kurang } & \multicolumn{2}{|c|}{ Total } & & \\
\hline & $\mathrm{N}$ & $\%$ & $\mathrm{~N}$ & $\%$ & $\mathrm{~N}$ & $\%$ & & \\
\hline Tidak & 27 & 81,8 & 6 & 18,2 & 33 & 100 & 0,0 & 840 \\
\hline Bekerja & & & & & & & 45 & 0 \\
\hline Bekerja & 11 & 52,4 & 10 & 39,1 & 21 & 100 & & \\
\hline Total & 38 & 70,4 & 16 & 29,6 & 54 & 100 & & \\
\hline
\end{tabular}
pekerjaan ibu tidak bekerja jumlah 33 orang (100\%) mayoritas tidak bekerja status gizi baik sebanyak 27 (81.8\%)dan status gizi kurang sebanyak 6 orang $(18,2 \%)$. Dan Varaibel pekerjaan yang bekerja sebanyak 21 orang $(100 \%)$ dimana status gizi baik sebanyak 11 orang $(52,4 \%)$ dan status gizi kurang sebanyak 10 orang $(39,1 \%)$.

Tabel 12 Hubungan Antara Jumlah anak dengan Status Gizi Balita di Puskesmas Hinai Kiri Kecamatan Secanggang Kabupaten Langkat tahun 2020

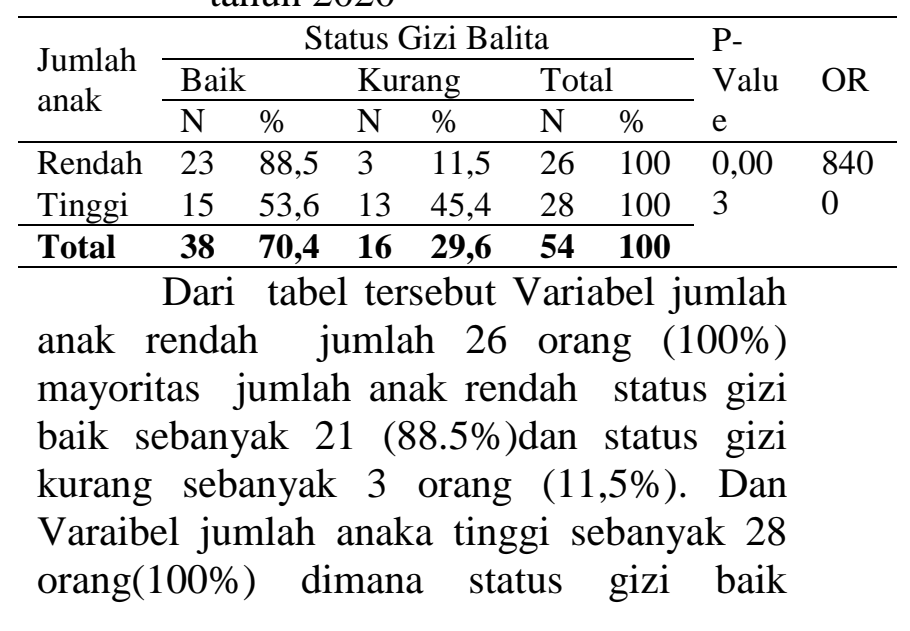


sebanyak 15 orang $(53,6 \%)$ dan status gizi kurang sebanyak 13 orang $(45,4 \%)$.

Tabel 13 Hubungan Antara penghasilan ibu dengan status gizi balita di Puskesmas Hinai Kiri Kecamatan Secanggang Kabupaten Langkat tahun 2020

\begin{tabular}{|c|c|c|c|c|c|c|c|c|}
\hline \multirow{3}{*}{$\begin{array}{l}\text { Penghasilan } \\
\text { ibu }\end{array}$} & \multicolumn{6}{|c|}{ Status Gizi Balita } & \multirow{3}{*}{\multicolumn{2}{|c|}{$\begin{array}{l}\text { P- } \\
\text { Va } \\
\text { lue }\end{array}$}} \\
\hline & \multicolumn{2}{|c|}{ Baik } & \multicolumn{2}{|c|}{ Kurang } & \multicolumn{2}{|c|}{ Total } & & \\
\hline & $\mathrm{N}$ & $\%$ & $\mathrm{~N}$ & $\%$ & $\mathrm{~N}$ & $\%$ & & \\
\hline & 24 & 92 , & 8 & 77 & 33 & 10 & 0,0 & 12 \\
\hline & 1 & 50,0 & 14 & 50.0 & 21 & 100 & 02 & \\
\hline Total & 38 & 70,4 & 16 & 29,6 & 54 & 100 & & \\
\hline
\end{tabular}

Dari tabel tersebut Variabel penghasilan ibu tinggi jumlah 33 orang (100\%) mayoritas penghasilan tinggi status gizi baik sebanyak $24(92,3 \%)$ dan status gizi kurang sebanyak 2 orang $(7,7 \%)$. Dan Varaibel penghasilan rendah sebanyak 21 orang $(100 \%)$ dimana status gizi baik sebanyak 14 orang $(50,0 \%)$ dan status gizi kurang sebanyak 14 orang $(50,0 \%)$.

\section{Hubungan Umur Ibu Dengan Status Gizi Balita.}

Sebagian besar umur responden pada penelitian ini adalah berumur $>35$ tahun.Dari hasil analisis statistic didapat bahwa terdapat hubungan yang bermakna antara umur dengan status gizi balita. Hal ini sejalan dengan hasil penelitian yang dilakukan Alibbirwin (2013) yang menyatakan bahwa kecenderungan ibu yang berumur > 35 tahun mempunyai Balita yang berstatus Gizi kurang ,lebih banyak dibandingkan ibu berumur $<35$ tahun.Menurut Karyadi (2010) status gizi anak Balita yang paling baik adalah mereka yang mempunyai ibu berusia $20-30$ tahun.Lebih muda atau lebih tua dari umur tersebut memperlihatkan kecenderungan status gizi anak Balita masih rendah.Sebagaimana ditemukan oleh Muscat (2012) umur ibu dapat dijadikan indicator taraf kesehatan balitanya. Ibu yang brumur tua mungkin sudah lelah mengurus rumah tangga sehingga mempengaruhi status gizi. Pada penelitian yang dilakukan penulis menunjukkan ada hubungan yang bermakna antara umur ibu dengan gizi Balita.Kebermaknaan penemuan penelitian ini diduga karena umur bisa merupakan menjadi faktor penyebab yang mempengaruhi status gizi dari kemungkinan hal ini terjadi karena salah satu adat kebiasaan ibu yang memiliki bayi memberikan ASI sampai umur dua tahun.

\section{Hubungan Pendidikan Ibu Dengan Status Gizi Balita}

Latar belakang pendidikan ibu merupakan salah satu unsur penting yang ikut menentukan keadaan gizi anak.Hubungan positif antara tingkat pendidikan orang tua dengan keadaan gizi anak telah banyak diungkap oleh para peneliti. Pada penelitian ini ada hubungan bermakna antara pendidikan ibu dengan status gizi balita. Hal ini sesuai dengan penelitian Ginting.M (2011), diperoleh hubungan yang signifikan antara tingkat pendidikan ibu dengan status gizi balita $(\mathrm{P}=0.004)$. Supariasa (2012) memandang latar belakang pendidikan orang tua yang kemungkinan berhubungan dengan status gizi yaitu pendidikan ibu. Seorang ibu akan menentukan bagaimana praktek pengasuhan anak termasuk praktek pemberian makanan pada bayi. Menurut Mutmainah (2010) rendahnya pendidikan orang tu menyebabkan rendahnya pemahaman terhadap apa yang dibutuhkan pada pengasuhan dalam perkembangan optimal anak.

Hasil temuan penelitian ini bermakna atau ada hubungan antara pendidikan dan status gizi diduga karena pendidikan adalah factor langsung yang mempengaruhi status gizi, namun terlebih dahulu pendidikan berpengaruh terhadap tingkat pengetahuan gizi.Pendidikan yang tinggi berkaitan erat dengan pengetahuan yang memungkinkan dimilikinya informasi tentang gizi dan kesehatan yang lebih baik sehingga dapat mendorong terbentuknya perilaku yang lebih baik. Pengetahuan kesehatan dan gizi merupakan factor yang menonjol dalam mempengaruhi pola konsumsi makan. Meskipun daya beli terhadap makanan 
tinggi, tetapi bila tidak disertai pengetahuan gizi, masalah gizi akan tetap dapat terjadi ( Sediaaoetama, 2016).

\section{Hubungan Status Pekerjaan Ibu Dengan Status Gizi Balita}

Seorang ibu yang bekerja sebagai pencari nafkah diluar rumah, berarti sebagian dari waktunya akan tersita, sehingga peranannya dalam hal mempersiapkan makanan terpaksa dikerjakan oleh orang lain, demikian juga pemberian makanan terhadap anak anaknya. Seorang ibu yang bekerja diluar rumah hendaknya dapat benar - benar membagi waktunya agar tugas - tugas rumah tangga dapat diselesaikan dengan baik, anak - anak juga mendapat perhatian dan pekerjaan kantornya tidak terlantar (Suhardjo, 2013).Pada penelitan yang dilakukan penulis menunjukan ada hubungan yang bermakna antara status pekerjaan ibu dengan status gizi Balita. Hal ini sesuai dengan hasil penelitian yang dilakukan Basuki,U(2014) uji statistic menunjukan adanya hubungan yang bermakna. Tampaknya Balita gizi kurang yang ibunya bekerja hampir sama peranannya dengan ibu yang tidak bekerja dalam menentukan kesehatan Balitanya. Sedangkan menurut Hidayati (2015) ibu yang bekerja diluar rumah cenderung memiliki waktu yang lebih terbatas.

\section{Hubungan Jumlah Anak Yang Dimiliki Ibu Dengan Status Gizi Balita}

Keluarga banyak anak akan menimbulkan banyak masalah. Dalam acara makan bersama sering kali anak yang kecil mendapatkan jatah makanan yang kurang mencukupi karena kalah dengan kakaknya yang makannya lebih cepat. Anak yang terlalu banyak selain menyulitkan dalam mengurusnya juga kurang biasa menciptakan suasana tenang di dalam rumah. Lingkungan keluarga yang selalu ribut akan mempengaruhi ketenangan jiwa dan ini secara tidak langsung menurunkan nafsu makan anggota lain.

Jumlah anggota keluarga yang besar akan mempengaruhi distribusi makanan kepada anggota keluarga lain, terutama pada anggota keluarga yang miskin yang terbatas kemampuannya dalam mnyediakan pangan sehingga akan beresiko terjadi kurang gizi. Hasil penelitian ini menunjukan ada hubungan yang bermakna antara Jumlah anak dengan status gizi balita, sedangkan penelitian oleh Amaral,Pedro (2010) adanya hubungan yang bermakna antara jumlah anggota keluarga dengan status gizi balita demikian pula yang dilakukan Miko (2012) hasil uji statistic adanya hubungan yang bermakna terjadi kurang gizi dalam lingkungan keluarga besar dengan anak dalam lingkungan keluarga kecil.

Adanya hubungan yang bermakna secara statistic pada penelitian ini kemungkinan ibu tetap dapat merawat anaknya dengan baik tanpa memandang anaknya lebih dari satu, terlebih sebagian besar ibu tidak bekerja sehingga mempunyai banyak waktu untuk memberikan perhatian kepada anaknya.Selain itu banyaknya keluarga (ibu, mertua, kakak, dan lain - lain) yang ikut membantu merawat anak anaknya karena sebagian besar responden hidup bersama dengan mereka.

\section{Hubungan Pendapatan Keluarga Dengan Status Gizi Balita}

Soekirman (2016) salah satu factor yang menentukan konsumsi makanan adalah penghasilan keluarga, demikian pula Berg (2012) pendapatan yang meningkat akan menyebabkan semakin besar total pengeluaran termasuk besarnya pengeluaran untuk makanan, dengan pengeluaran untuk makanan yang semakin besar akan mengakibatkan lebih banyak makanan yang dibeli. Keterbatasan penghasilan keluarga turut menentukan mutu makanan yang disajikan. Tidak dapat disangkal bahwa penghasilan keluarga akan turut menntukan mutu makanan yang disajikan untuk keluarga sehari - hari, baik kualitas maupun jumlah makanan. Dari uji statistik didapatkan bahwa ada hubungan yang bermakna antara pendapatan dengan status gizi balita.Hasil Penelitian ini sesuai dengan penelitian yang dilakukan Amaral,Pedro (2010) berdasarkan uji statistik 
menunjukkan adanya hubungan yang bermakna antara pendapatan dengan status gizi balita. Kebermaknaan pada penelitian ini kemungkinan ketersediaan keanekaragaman bahan makanan yang dibeli banyak sehingga keluarga yang berpendapatan tinggi dapat membeli makanan yang bergizi tinggi dan bahan makanan yang tersedia memenuhi syarat kecukupan zat gizi. Dan Cuma kadang kadang orang tua lebih banyak diperuntukkan bagi pembelian barang barang lain serta kebiasaan cara pengolahan makanan yang tidak baik sehingga zat - zat gizi yang terkandung hilang.

\section{Simpulan}

Dari hasil penelitian didapatkan bahwa sebesar $70,4 \%$ balita tidak kurang gizi, hal ini disebabkan karena keadaan masyrakat di Puskesmas Hinai Kiri Kecamatan Secanggang merupakan komunitas yang homogeny baik sikap, perilaku, lingkungan adat kebiasaan sehingga dapat mempengaruhi keadaan Balita yang diasuhnya.

Adanya hubungan yang bermakna antara factor ibu (Pengetahuan, umur, pendidikan, status pekerjaan, jumlah anak, Pendapatan) dengan status gizi balita di Puskesmas Hinai Kiri. Diantara factor ibu yang paling berhubungan secara dominan mempengaruhi kejadian balita dengan kurang gizi adalah yaitu penghasilan. Dari hasil analisis tersebut didapatkan bahwa Balita yang penghasilan kurang memiliki resiko 12 kali lebih besar mengalami kurang gizi dibandingkan dengan balita yang keluarga yang punya pengahsilan tinggi. Dengan Penghasilan keluarga yang lumayan kemungkinan ketersediaan keanekaragaman bahan makanan yang dibeli banyak sehingga keluarga yang berpendapatan tinggi dapat membeli makanan yang bergizi tinggi dan bahan makanan yang tersedia memenuhi syarat kecukupan zat gizi.

\section{Daftar Pustaka}

Akdon, H. S. (2014) Aplikasi Statistika dan Metode Penelitian untuk administrasi dan manajemen. Bandung: Dewa Ruchir.
Almatsier, S. (2013) Prinsip- prisnsip Ilmu Gizi. Jakarta: Gramedia Pustaka Utama.

Depkes, R. (2016) Profil kesehatan indonesia. Jakarta: Depkes.RI.

Manuaba, I. (2015) Ilmu Kebidanan, Penyakit Kandungan dan Keluarga Berencana untuk Pendidikan Bidan. Jakarta: EGC.

Profil Kesehatan (2017) Profil Kesehatan Langkat. Available https://docplayer.info/123141703-Profilkesehatan-kabupaten-langkat-tahun2017.html (Accessed: 12 September 2020).

Supariasa (2012) Penilaian Status Gizi. Jakarta: EGC. 